\title{
Lumen
}

Selected Proceedings from the Canadian Society for Eighteenth-Century Studies

\section{The Impartial Spectator, amour-propre, and Consequences of the Secular Gaze: Rousseau's and Adam Smith's Responses to Mandeville}

\section{Nigel Joseph}

Volume 30, 2011

URI : https://id.erudit.org/iderudit/1007714ar

DOI : https://doi.org/10.7202/1007714ar

Aller au sommaire du numéro

Éditeur(s)

Canadian Society for Eighteenth-Century Studies / Société canadienne d'étude du dix-huitième siècle

ISSN

1209-3696 (imprimé)

1927-8284 (numérique)

Découvrir la revue

Citer cet article

Joseph, N. (2011). The Impartial Spectator, amour-propre, and Consequences of the Secular Gaze: Rousseau's and Adam Smith's Responses to Mandeville.

Lumen, 30, 33-44. https://doi.org/10.7202/1007714ar

Copyright (c) Canadian Society for Eighteenth-Century Studies / Sociéte canadienne d'étude du dix-huitième siècle, 2011
Ce document est protégé par la loi sur le droit d'auteur. L'utilisation des services d'Érudit (y compris la reproduction) est assujettie à sa politique d'utilisation que vous pouvez consulter en ligne.

https://apropos.erudit.org/fr/usagers/politique-dutilisation/ 


\section{The impartial spectator, amour- propre, and consequences of the secular gaze: Rousseau's and Adam Smith's responses to Mandeville}

Jean-Paul Sartre and Michel Foucault have been prominent among those who have, in recent years, sensitized us to aspects of "the gaze," to the dynamics of the process by which we simultaneously watch others and are aware of being watched by them. ${ }^{1}$ If Sartre (Being and Nothingness, 1943) has explored, with unparalleled penetration and thoroughness, the way in which "the hypertrophy of the visual lead[s] to a problematic epistemology, abet[s] the domination of nature, ... support[s] the hegemony of space over time ... [and] produce[s] profoundly disturbing intersubjective relations and ... a dangerously inauthentic version of self, ${ }^{\prime 2}$ Foucault (Discipline and Punish, 1975) has helped to make familiar the idea of a "carceral" society, members of which are rendered docile and governable by constant surveillance. Thus, with Foucault, we may experience the gaze of others as surveillance, as intrusive and coercive, as that which renders us governable and biddable; and with Sartre, we may experience the gaze as a stimulus to performance, as the basis for all kinds of inauthenticity. In addition, we may experience the gaze in a more prosaic way, one that both Sartre and Foucault tend to treat with some disdain, perhaps because it is so transparently bourgeois: I mean, of course, the gaze that is experienced as simultaneously imposed upon us and autonomously chosen, the gaze as basis of an everyday morality.

1 Jean-Paul Sartre, Being and Nothingness: A Phenomenological Essay on Ontology, trans. Hazel E. Barnes (New York: Pocket Books, 1956); Michel Foucault, Discipline and Punish: The Birth of the Prison, trans. Alan Sheridan (New York: Vintage Books, 1995).

2 Martin Jay, Downcast Eyes: The Denigration of Vision in Twentieth-Century French Thought (Berkeley: University of California Press, 1993), 276. 
Thus we may interpret the gaze in three different ways: as surveillance, as stimulus to performance, and as securing morality. These are, however, analytic distinctions. In our everyday existence we are more likely to experience the gaze of others as so fleetingly embodying one of these states and passing into another that it is impossible to separate them. This is perhaps the typically modern experience of the gaze of others: we move restlessly and incessantly between suspicion of the gaze and relief that it rests upon us with indifference or approval, experiencing it sometimes as supportive and generative, and at other times as hostile, enervating, and burdensome.

It is interesting that a version of this set of positions, this provisional tripartite distinction, is to be found much earlier, in writings of the early to mid-eighteenth century. Modern debates about the gaze, such as those between Sartre and Maurice Merleau-Ponty, and those between Foucault and his critics, are uncannily like a particular debate that took place much earlier. The idea that the gaze of others may be experienced as surveillance, an idea we have come to associate with George Orwell or Michel Foucault, seems to be an idea of relatively recent provenance, but in fact, as I shall argue, it is a distinctive feature of the thought of Bernard Mandeville, the man who was responsible for provoking both Rousseau and Smith into articulating some of their most characteristic and influential ideas. Mandeville, like Foucault, reads the gaze as a means by which power maintains itself and renders us tractable and governable subjects. Thus, Mandeville's arguments anticipate those of Foucault, and he provokes responses from Rousseau and Adam Smith, who in turn, and in striking ways, anticipate the arguments of Sartre and Merleau-Ponty. If we examine Mandeville's The Fable of the Bees (1714, 1723), Rousseau's Discourse on the Origin of Inequality (1755), and Smith's The Theory of Moral Sentiments (1759), we see the gaze being explored, perhaps for the first time, as surveillance, as a source of inauthenticity, and as the basis of morality. ${ }^{3}$ Mandeville suggests that our awareness of the gaze of others becomes the route by which "skilful politicians" make us into docile subjects; Rousseau's writings revolve obsessively around the notion of the gaze as stimulus to inauthenticity; and Smith chooses to emphasize that the gaze, embodied in the

3 Bernard Mandeville, The Fable of the Bees: Or Private Vices, Publick Benefits, ed. F.B. Kaye, 2 vols (Indianapolis: Liberty Fund, 1988); Jean-Jacques Rousseau, A Discourse on the Origin of Inequality in The Social Contract and Discourses, trans. G.D.H. Cole (London: J.M. Dent, 1973), 27-113; Adam Smith, The Theory of Moral Sentiments, ed. D.D. Raphael and A. L. Macfie (Indianapolis: Liberty Fund, 1984). 
figure of the impartial spectator, may be the foundation of an everyday morality. ${ }^{4}$

The arguments of Rousseau and Smith are fairly well known. Mandeville, on the other hand, the writer whose intellectual presence can be sensed behind the Discourse and the Theory of Moral Sentiments, is a relatively neglected figure. And yet this is the man who wrote The Fable of the Bees, one of the most widely read and provocative texts of the eighteenth century; who influenced and stimulated Hume, Smith, Rousseau, Berkeley, Joseph Butler, and Hutcheson; who wrote widely read parodies of Addison and Steele's Essays; who was read carefully by Samuel Johnson, who confessed that Mandeville had "opened [his] views into real life very much"; who was read closely by philosophers as far apart as Immanuel Kant and Karl Marx; who Macaulay claimed had more penetrating insight into human motives than Shakespeare did; whom both Richardson and Fielding had read and were clearly responding to, especially in Richardson's Sir Charles Grandison and Fielding's Amelia; and who was the first to articulate the paradox of the unintended social consequences of luxury, the paradox that became one of the foundations of modern capitalism. ${ }^{5}$

The question of why Mandeville is no longer so widely read as he used to be obviously is a complex one; but one important clue to the specific nature of the fear and distaste that Mandeville provoked (and I would suggest, continues to provoke) is provided by J.G. A Pocock in The Machiavellian Moment:

Mandeville, whose principal works appeared between 1714 and 1732, won a reputation in his time akin to those of Machiavelli and Hobbes in theirs, by proclaiming that 'private vices' were 'public benefits.' ... He argued that the

4 These are, as I have indicated, very general analytic categories, to be applied provisionally and pragmatically. The thought of Mandeville, Rousseau and Smith can hardly be pigeonholed so neatly, even where a single theme is concerned. Mandeville, for instance, like Rousseau after him, also implies that the gaze promotes inauthentic behaviour; and, as Smith does later, Mandeville also sees the gaze as feeding into an everyday morality. Unlike both Rousseau and Smith, however, he eschews the role of concerned moralist, and chooses to present himself as an amused outsider, above the fray.

5 For a good account of Mandeville's influence on other thinkers, see Kaye's introduction to his edition of The Fable, especially cxiv-cxlvi. For an account of his more recent influence, see E.G. Hundert, The Enlightenment's Fable: Bernard Mandeville and the Discovery of Society, (Cambridge: Cambridge University Press, 1994), 23749. 
mainspring of social behaviour was not self love ... but what he called selfliking ... based on the figure one cut in one's own eyes and those of others ... . At bottom he was saying that the real world of economy and polity rested on a myriad fantasy worlds maintained by private egos; and he deeply disturbed his contemporaries, less by telling them they were greedy and selfish than by telling them they were unreal ... . The specter of false consciousness had arisen, and was proving more frightening than that of Machiavellian realpolitik. ${ }^{6}$

It is this unreality evoked by Mandeville that so shocked Rousseau, and can still, I believe, shock us today. For Mandeville, the world of moral actions can be reduced to our desire to appear in a flattering light in the eyes of the world. Mandeville's most provocative and most famous argument is, briefly, that private vices lead to public benefits, that the selfish pursuit of luxuries, traditionally condemned by religious leaders and moralists of every stripe, was in reality the engine of progress and national prosperity. This argument has by now been so thoroughly internalized as an early version of laissez faire economic thought that it has lost its power to shock. Indeed, one of the reasons Mandeville is not widely read today may have to do with the fact that so many thinkers (among them, of course, Adam Smith) mined and domesticated Mandeville so successfully that his ideas do not sound particularly original. But the second set of ideas that Mandeville explored still has the potential to disturb; it is these ideas that Pocock has in mind when he writes of Mandeville's impact on his contemporaries.

Mandeville believes, or claims to believe, that all moral actions are undertaken in order to gain the approval of others. To him, the Kantian argument that the truly moral action is the autonomous one would make no sense at all. Mandeville argues that manipulative leaders, men he calls "lawgivers and other wise men," and at other times, less charitably, lawyers and politicians, have convinced people that "it was more beneficial for every Body to conquer than indulge his Appetites." 7 They did this by instructing men "in the Notions of Honour and Shame." Politicians, by teaching men to love honour and fear shame, made them docile and subservient. Mandeville never tires of mocking the claims made on behalf of honour: "By Honour, in its proper and genuine sig-

6 J.G.A Pocock, The Machiavellian Moment: Florentine Political Thought and the Atlantic Republican Tradition (Princeton: Princeton University Press, 1975), 465-66.

7 Mandeville, 1, 42.

8 Mandeville, 1, 43. 
nification, we mean nothing else but the good Opinion of others." ${ }^{\prime 9}$ And, again: "Honour in its Figurative Sense is a Chimera without Truth or Being, an Invention of Moralists and Politicians, and signifies a certain Principle of Virtue not related to Religion, found in some men that keeps 'em close to their Duty and Engagements whatever they be .... ."10

Mandeville is not a particularly systematic thinker, and he sometimes forgets about the manipulative leaders. But this very lack of consistency proves useful. Dropping the "skilful politicians" allows Mandeville to posit something far more interesting: the fact that our reliance on the opinions of others can become an autonomous structure, one that defines modern societies. In any case, whatever particular form the argument takes, Mandeville is consistent in arguing that any moral act may be explained in terms of the individual's desire to fit in, to be admired, liked, gazed at with approval. Beginning with the simple desire for "the Approbation, Liking and Assent of others,"11 he goes on to posit a "self-liking" based on this desire for approval that is "so necessary to the Well-being of those that have been used to indulge it ... that they can taste no Pleasure without it.." ${ }^{\prime 2}$ In Mandeville's vision, human motivation and action emerge from a nightmarish hall of mirrors in which every human unit is obsessively concerned with his or her reflection in the eyes of all the others: nightmarish because of Mandeville's insistence that there is nothing else but this concern. It is this aspect of Mandeville's thought that Rousseau responds to above all in his Discourse. Picking up on Mandeville's sardonic reductiveness and amplifying it, Rousseau develops a throughgoing critique of modernity as shallow, as essentially other-centered in the worst possible way. "Social man ... receive[s] the consciousness of his own existence merely from the judgment of others concerning him," writes Rousseau bitterly. ${ }^{13}$ Sartre, writing nearly two centuries later, echoes him: "I am for myself only as I am a pure reference to the Other." ${ }^{14}$

Rousseau and Smith, in their writings of 1755 and 1759, are perhaps the first to express their conception of the secular gaze as problematic, as both potentially deeply troubling and as a significant resource; and

9 Mandeville, 1, 63.

10 Mandeville, 1, 198.

11 Mandeville, 2, 130.

12 Mandeville, 2, 136.

13 Rousseau, 104.

14 Sartre, 349. 
they do so largely because Mandeville had depicted the mutuality of the gaze as a phenomenon that was disturbingly ubiquitous, potentially anarchic, and subversive of traditional morality. To put it differently, they are able to do so because, for the first time, in the mid eighteenth century, the gaze could be, perhaps had to be, theorized as a secular phenomenon, distinct from the Augustinian dialectic in which man and his Maker contemplate each other. At the mid-century point, thinkers like Rousseau and Smith become sharply aware that Europeans had imperceptibly slipped into a new way of negotiating the mutuality of the gaze. Instead of an Augustinian world in which ultimate ontological security lay in the sense that one reposed in the gaze of God, one was transported into a world in which one was stripped, laid bare, unmasked, by the gaze of ones fellow citizens. Augustine, writing in the $4^{\text {th }}$ century A.D., ends his Confessions with an invocation of the gaze of the Deity: "We therefore see these things which Thou madest, because they are; but they are, because Thou seest them. And we see without, that they are, and within, that they are good, but Thou sawest them there, when made, where Thou sawest them, yet to be made." ${ }^{15}$ Things are sanctified by the gaze of God, and Augustine's Confessions themselves are an intimate, passionate, agonized dialogue with the God who "sees" him.

Rousseau, a belated Augustine who writes his own Confessions, cannot achieve the hard-won serenity and poise of his predecessor. With the sensibility of an Augustine, he finds himself among atheists and rationalists, and his writing is suffused with regret at the loss of an unmediated relationship with the Deity. Instead of the gaze of God, Rousseau is aware only of the lacerating and destabilizing gaze of critical contemporaries. In addition to a generalized sense of the loss of an organizing and morally comforting divine presence, Rousseau was also responding to what he saw as an unjustified and provocative complacency among writers who registered this loss as he did, but, quite unaccountably, seemed to celebrate it. Among these, Mandeville was probably the most prominent and the one who most powerfully aroused in Rousseau a sense of outrage. Rousseau refers to him in the Discourse as possessing a "cold subtlety of style,"16 yet he also borrows heavily from Mandeville's conjectural history of the origins of manners and politeness.

15 Augustine, The Confessions, trans. Edward Pusey (Chicago: Encyclopedia Brittanica, 1952), 124.

16 Rousseau, 67. 
In marked contrast to Mandeville, Rousseau invariably responds to the gaze with suspicion and horror. In a famous passage in the Discourse on the Origin of Inequality he writes:

Everything now begins to change its aspect. Men, who have up to now been roving in the woods, by taking to a more settled manner of life, come gradually together, form separate bodies, and at length in every country arises a distinct nation ... Men began now to take the difference between objects into account, and to make comparisons; they acquired imperceptibly the ideas of beauty and merit, which soon gave rise to feelings of preference .... They accustomed themselves to assemble before their huts round a large tree; singing and dancing, the true offspring of love and leisure, became the amusement, or rather the occupation, of men and women thus assembled together with nothing else to do. Each one began to consider the rest, and to wish to be considered in turn; and thus a value came to be attached to public esteem. Whoever sang and danced best, whoever was the handsomest, the strongest, the most dexterous, or the most eloquent, came to be of most consideration; and this was the first step towards inequality, and at the same time towards vice. ${ }^{17}$

From this perception of the corrupting effect of the gaze, Rousseau concludes that "civilized man ... receive[s] the consciousness of his own existence merely from the judgment of others concerning him." Beginning in a healthy amour de soi, he is steadily drawn into an unhealthy amour-propre, a state triggered by awareness of the gaze of others. Rousseau's text is thus one of the origins of a tradition of suspicion of the secular, public gaze: a tradition that culminates in Sartre's extended explorations of inauthenticity in Being and Nothingness. For Rousseau, as for Sartre, hell is other people, and for both writers an awareness of being the focus of the gaze leads the subject to hyperbolized and inauthentic performance.

Rousseau's Discourse was read and reviewed by Adam Smith, whose Theory of Moral Sentiments was published only four years later, and who, like Rousseau, was fascinated by the possibilities of the gaze. But where Rousseau sees nothing but envious and manipulative performance, Smith sees an opportunity for the grounding of moral order and stability. Where Rousseau writhes and struggles under the gaze of the other, in Smith's equable prose the gaze is used to stabilize and rationalize the potentially anarchic energies of the modern subject: 
The principle by which we naturally either approve or disapprove of our own conduct, seems to be altogether the same with that by which we exercise the like judgments concerning the conduct of other people. We either approve or disapprove of the conduct of another man according as we feel that, when we bring his case home to ourselves, we either can or cannot entirely sympathize with the sentiments and motives which directed it. And, in the same manner, we either approve or disapprove of our own conduct, according as we feel that, when we place ourselves in the situation of another man, and view it, as it were, with his eyes and from his station, we either can or cannot entirely enter into and sympathize with the sentiments and motives which influenced it. We can never survey our own sentiments and motives, we can never form any judgment concerning them; unless we remove ourselves, as it were, from our own natural station, and endeavour to view them with the eyes of other people, or as other people are likely to view them ... We endeavour to examine our own conduct as we imagine any other fair and impartial spectator would examine it. $^{18}$

In his review of Rousseau's Discourse, Smith had mentioned, as of a matter beyond dispute, that "the Fable of the Bees has given occasion to the system of Mr Rousseau. ${ }^{\prime 19}$ As Smith noted, Rousseau had taken over Mandeville's conjectural history of human development; but most importantly, Rousseau had also taken over Mandeville's gleeful description of the promiscuous reciprocity of the gaze, its tendency to stir up competitive desire. But Mandeville's delight in this promiscuity is replaced, in Rousseau, by a kind of elegiac intensity: for Rousseau, the mutually evaluating gaze was "the first step towards inequality, and at the same time towards vice."

In a sense, both Rousseau and Smith agree with Mandeville: they merely shift the emphasis in certain ways. Rousseau is substantially in agreement with Mandeville about the deludedness of human beings concerning their moral life. The difference lies in the response to this deludedness. Mandeville is brutally cheerful, pointing out that this deludedness leads to wealthy and secure societies. As Maurice Goldsmith paraphrases Mandeville's logic, "Seeking the approbation of others enables humans to be formed into large, interdependent

19 Adam Smith, "A Letter to the Authors of the Edinburgh Review," in The Early Writings of Adam Smith, ed. J. Ralph Lindgren (Augustus M. Kelley: Reprints of Economic Classics, 1967), 24. 
organizations. ${ }^{\prime 20}$ Rousseau, whose critique is a secularized republican version of the scriptural teaching that it profits not a man to gain the world if he lose his immortal soul, rejects the idea that a wealthy and stable society may be a good in itself.

It is on precisely this issue that Smith is most in agreement with Mandeville. Temperamentally different from Rousseau, he seizes on Mandeville's argument that the desire to be approved of by others "enables humans to be formed into large, interdependent organizations." Alert to the possibility that commercial societies acquire a complex internal momentum that is based on the enduringness of the appetites and an obsessive desire to be admired, rather than on traditional morality, Smith is willing to agree with Mandeville up to a point. But Smith must distance himself from Mandeville's tone, his cynical "I can see through all moral positions" stance. As E. G. Hundert puts it: "Smith placed himself on Mandeville's side of the dispute between strict Christian or classical ethics and the modern habits of civility which Rousseau had most influentially characterized as degraded. Yet he wished at the same time to resist the wider licentious implications of Mandeville's line of reasoning. ${ }^{\prime 21}$ Smith, writing his Theory of Moral Sentiments with the double knowledge that Mandeville had struck on a truth of immense significance and that he had explicated this truth in the most provocative and subversive prose, has a delicate task before him. He must present the desire to be approved of by others as somehow in line with conventional morality; but he must also allow considerable room for self-interest and the expansive desires of the individual in modern commercial societies. This, I believe, accounts for the slipperiness of Smith's Theory of Moral Sentiments, the feeling the reader often gets that he or she is reading something perfectly straightforward and familiar, but at the same time that the argument as a whole cannot easily be paraphrased.

That this debate about the gaze remains unresolved in significant ways, that it is still, in some sense, a very live issue, is indicated by the fact that a version of the debate was repeated fairly recently. I will conclude by sketching, very schematically and briefly, the ways in which this three-cornered debate between Mandeville, Rousseau and Smith is

20 Maurice Goldsmith, Private Vices, Public Benefits: Bernard Mandeville's Social and Political Thought (Christchurch, New Zealand: Cybereditions, 2001), 152.

21 Hundert, 223. 
replicated in the twentieth century, with significant shifts of emphasis, by Sartre, Maurice Merleau-Ponty, and Foucault. ${ }^{22}$

In his long disquisition on "The Existence of Others" in Being and Nothingness, Sartre obsessively returns to the image of the self being trapped and alienated by "the look":

... if the Other-as-object is defined in connection with the world as the object which sees what I see, then my fundamental connection with the Other-asobject must be able to be referred back to my permanent possibility of being seen by the Other ... . Being-seen-by-the-Other is the truth of "seeing-the-Other" ... . The Other's look hides his eyes; he seems to go in front of them ... . I grasp the Other's look at the very center of my act as the solidification and alienation of my own possibilities ... . The Other is the hidden death of my possibilities ... .Thus in the shock which seizes me when I apprehend the Other's look ... suddenly I experience a subtle alienation of all my possibilities ... ${ }^{23}$

This worry about loss of authenticity, about the "bad faith" encouraged in the one who is aware of being looked at, is clearly the same as Rousseau's, but here it is articulated in the language of existential phenomenology. Similarly, Foucault's cool analysis of disciplinary regimes, in which "[h]e who is subjected to a field of visibility ... inscribes in himself the power relation in which he simultaneously plays both roles; he becomes the principle of his own subjection, ${ }^{\prime 24}$ replicates the logic of Mandeville's analysis of honour and the compulsion to behave well. Mandeville, like Foucault, insists relentlessly on "visibility" as a weapon in the arsenal of governance. Finally, Smith, careful reader of Mandeville and Rousseau, reads this visibility, this focus on the gaze, not as corrupting or as feeding into a tyrannical power, but as the basis of an everyday morality. Eschewing the sardonic and subversive mockery of Mandeville, as well as the impassioned and outraged rhetoric of Rousseau, he sketches the outlines of a distinctively commercial and cosmopolitan morality, delicately poised between other-centeredness

22 Foucault comes after Sartre and Merleau-Ponty, of course, and therefore can hardly be said to provoke responses from them as Mandeville can be plausibly interpreted as provoking Rousseau and Smith; and I don't mean to imply that there is anything like a direct link between these two sets of thinkers. Rather, I am suggesting that when such a subject as "the gaze" becomes the focus of debate, certain polemical positions will inevitably be occupied.

Sartre, 344-54.

24 Foucault, 202. 
and self-interest. In like fashion, Merleau-Ponty, responding to Sartre in his Phenomenology of Perception (1945), maintains a tone of respectful disagreement and aims at a workable theoretical rapprochement, just as Smith does in responding to Rousseau. Where Sartre intemperately insists on the incompatibility between freedom and the constraining and binding effects of "the look of the Other," Merleau-Ponty, in a chapter revealingly entitled "Other People and the Human World," brilliantly and elegantly incorporates Sartre's intransigent reading of the hostile scopic encounter of mutually alienated individuals into his vision of a humanly interpenetrating world:

Once the other is posited, once the other's gaze fixed upon me has, by inserting me into his field, stripped me of part of my being, it will readily be understood that I can recover it only by establishing relations with him, by bringing about his clear recognition of me, and that my freedom requires the same freedom for others ... . I enter into a pact with the other person, having resolved to live in an interworld in which I accord as much place to others as to myself ... . Just as the instant of death is a future to which I have not access, so I am necessarily destined never to experience the presence of another person to himself. And yet each person does exist for me as an unchallengeable style or setting of co-existence, and my life has a social atmosphere just as it has a flavour of mortality.

Here Merleau-Ponty's delicate and respectful but nevertheless incisive rejection of the dead-end of Sartre's suspicion of the gaze is very like Smith's treatment of Rousseau. Where Rousseau and Sartre read the gaze as producing inauthentic performance, Smith and Merleau-Ponty insist on the mutuality of the gaze as constitutive of a distinctively human world (or interworld, as the latter calls it).

I will conclude by suggesting that these authors - Mandeville, Rousseau, Smith, Sartre, Merleau-Ponty, and Foucault, and others like them - must be read apart in order to be read together. On the one hand, their arguments about "the look" or "surveillance" or "the impartial spectator" may be ordered under a provisional rubric such as "the gaze," and this rubric may confer a kind of temporary unity that aids thinking. On the other hand, the actual arguments of these thinkers seem to pull violently in different directions. Perhaps, then, these texts are striking, not so much in their similarities or in their antithetical relationships to one another, but in what we might think of as

25 M. Merleau-Ponty, Phenomenology of Perception, trans. Colin Smith (London: Routledge and Kegan Paul, 1962), 364. 
their uncanny complementarity. Read together, these texts illuminate the schizophrenic nature of everyday performativity in the modern world. Mandeville treats the gaze almost as if it were a phenomenon in physics, beyond alteration, something to be studied; Rousseau sees this scrutiny as the basis of inauthenticity, unfulfillable desires, and "bad" performances; and Smith builds an entire morality of restraint and docility on the very same phenomenon. I want to suggest that these thinkers, when they are read against one another, capture a peculiar feature of modern subjectivity, that bizarre combination of the self's almost neurotic awareness of surveillance and of the judgmental and normalizing gaze of the generalized other, and the same self's constant and obsessive desire to transform the putative judgments into unambiguous approval of the self. The surveillance of other selves, mediated by the gaze, results in the schizophrenic reality we are familiar with: we thus inhabit a world that has, simultaneously, features of the respectable bourgeois public sphere, of the carceral society, and of the "society of the spectacle." Mandeville, Rousseau, and Smith and their heirs explore with a degree of theoretical autonomy what we experience as a conflicted totality: the totality of an aspiration to be unobtrusively good while rendering oneself a spectacle in an atmosphere of casual and yet unceasing surveillance.

NIGEL JOSEPH

University of Western Ontario 